\title{
Educational Reform of Chinese National Musical Instrument in Quality Education and Basic Music Education
}

\author{
Xiuhui Yu \\ Dongchang College Liaocheng University, Shandong Liaocheng 252000
}

Keywords: quality education; basic music education; Chinese national musical instrument education; educational reform

\begin{abstract}
Chinese national musical instrument in quality education and basic music education plays an inevitable role in the process of growth and development for students. Learning to play Chinese national musical instrument has presented the value of aesthetic experience, cultural inheritance and creative development, showed group consciousness and cooperation spirit and boosted moral education. However, schools and students lack Chinese national musical instrument learning. There is a lack of relevant teachers and teaching pattern is unitary. Therefore, it is necessary to change our mind and more attention should be paid to Chinese national musical instrument education. For national musical instrument education, it is necessary to optimize teaching staff, transform the traditional teaching pattern, focus on art practice course, push forward educational reform of Chinese national musical instrument in quality education and basic music education constantly and promote the development and inheritance of Chinese national musical instrument.
\end{abstract}

\section{Introduction}

There are 56 ethnic groups with their own life habits and national habits in China. Meanwhile, there are some precious spiritual culture and material culture treasure in each group which have become valuable heritages. Chinese national musical instrument is a component of the heritages and its presence and inheritance are of great importance for us. Facilitating the spread and development of Chinese national musical instrument is necessary by learning and inheriting national musical instrument. For inheriting and developing national musical instrument, one of the effective ways is to add Chinese national musical instrument into quality education and basic music education. However, there are lots of problems in Chinese national musical instrument teaching in quality education and basic music education, which requires us to carry forward reform and innovation.

\section{The Significance of Proceeding Chinese National Musical Instrument Teaching in Quality Education and Basic Music Education.}

An important part of traditional culture is Chinese national musical instrument. It is not only the duty and responsibility of culture section and scholars to protect and inherit Chinese national musical instrument, but also the obligation of all the society. We are required to commit ourselves to achieving the goal. For professional musical schools, basic music education is viewed as basic course and key point in work and Chinese national musical instrument is an important part of basic music education as well as of profound significance of spreading and inheriting Chinese national musical instrument culture. ${ }^{[1]}$

Chinese national musical instrument of our country is the crystallization of the wisdom of the people of all ethnic groups. With obvious aesthetic and cultural characteristics, it advocates the unity of life, aesthetics and art, and fully implements art from life. Carrying out Chinese national musical instrument education in quality education and basic music education is to apply the carrier of national musical instrument to lead students to music aesthetics. Rich national cultural connotations are contained in Chinese national musical instrument of our country, includes many 
aesthetic thoughts and humanistic feelings. Students have further improved their temperament and speech and behavior by learning national instrumental music, which makes them more elegant and musical. The aesthetic experience value and cultural heritage value in the course are directly reflected.

For the acting class with strong practicality and operability, Chinese national musical instrument attaches importance to the learning value of music itself. Students are required to learn by themselves through acting and playing. Theories and practices are perfecting combined, which embodies the central status of students in the process of studying. This study method has stimulated personalities and creativities of students and actually had their imagination and creation displayed when learning. Particularly, national musical instrument in our country contains rich feeling and national awareness, which require students to use their imagination to experience the artistic conception and integrate their feeling into play and creation of music truly. Actually, this reflects creative development value of musical courses. ${ }^{[2]}$

Chinese national musical instrument is diversified, including guzheng, pipa, bamboo flute, suona and other musical instruments. For the performance forms, ensemble, ensemble and ensemble, etc. are included. The colorful instruments and performance forms have their own features, which can make students play the characteristics of instrument and play more beautiful melody with the unbidden cooperation. All of this requires multiple students to cooperate. Students' group consciousness and unity and cooperation spirit can be cultivated to improve students' interpersonal skills by mutual cooperation. The abilities are qualified by students in the process of participating in social practice, which are also the most basic qualities and abilities of students and are conducive to growth and progress for students.

In recent years, our country has been calling upon implementing quality education. Due to the social fact and development situation of our country, implementing quality education is in slow pace. When carrying out quality education, we are required to focus on cultivating people by virtue. However, for the process of ideology education, it is very boring. Educational way should be transformed and carried out step by step. For all students, implementing national musical instrument in quality education and basic music education is to improve the comprehensive quality. National musical instrument represents outstanding national culture of our country and contains rich traditional culture. The role of national instrumental music in education is far beyond other kind of education. It stimulates students' interests without compulsive factors via artistic activities to impress people's emotions and make students carry out learning activities happily.

\section{The Current Situation of National Musical Instrument in Quality Education and Basic Music Education}

In cultivating music culture and aesthetic accomplishment as well as improving comprehensive quality of students, national musical instrument teaching in quality education and basic music education is of great importance. At present, few attentions have been paid to national musical instrument teaching in quality education and basic music education in our country. National musical instrument in many colleges is just viewed as an interest class or an elective course. It is considered that national musical instrument is dispensable, which leads to many problems in national musical instrument teaching in quality education and basic music education.

Whether it is compulsory education, secondary education, higher education or vocational education, there are related courses in music education as public courses at all stages of education in China, and students are taught some basic music knowledge and theory. However, in our country's music education, it is just to teach students a few songs simply. For national musical instrument, the students only have access to the learning through the interest class because national musical instrument teaching is required to be combined with fixed instruments to learn, it is necessary to carry out continuous practice and take a lot of time, money and effort. ${ }^{[3]}$ Students are forced to give up their learning due to the pressure of study, examinations, and opposition from parents and teachers though they have the idea and interest of learning national musical instrument.

Teachers with professional qualities are required to take up teaching work as national musical 
instrument is a major with strong professional and operability. On one hand, others who have not received professional training and learning are difficult to master the characteristics and usage methods of these national musical instruments. On the other hand, our country's national musical instruments are abundant and diverse. These are our precious national treasures, and various musical instruments have their own characteristics. Each student has different interest and choices for national instrumental music. For teachers, there are the national musical instrument that are good at or not. Therefore, it is difficult to meet the needs of all students, and multiple teachers are required to cooperate. This has led to the lack of national instrumental music teaching teachers in quality education and basic music education in China, which has hindered the development of teaching activities. ${ }^{[5]}$

A detailed curriculum plan developed by the teacher is demanded in the process of specific teaching and a variety of knowledge is imparted in time and chapters. However, the knowledge of the music is very diverse. For music teachers, a person may be responsible for teaching in multiple classes. With high work pressure, large course content and limited teachers' energy, it will result in wide-range content in the process of teaching with a wide range and a large framework, and many contents have not been analyzed and explained in depth. For the teaching of national musical instrument, teachers often pay attention to the teaching of theory. Due to the single teaching mode, the specific instrument operation and application are neglected, which makes the theory and practice of students' national musical instrument learning be out of touch. ${ }^{[4]}$

\section{Reform Measures of National Musical Instrument Teaching in Quality Education and Basic Music Education}

Carrying forward national musical instrument teaching in quality education and basic music education contributes to improving student's aesthetic awareness and ability, enhancing their comprehensive quality and literacy, promoting the spread and inheritance of national musical instrument and protecting excellent national cultural heritage of our country. However, all of these require joint effort from country, society, colleges, teachers, parents and students to take a series of measures to reform national musical instrument teaching in quality education and basic music education in order to cultivate more talents for society.

Nowadays, national musical instrument teaching in quality education and basic music education of our country has got few attentions. Neither the schools, teachers, parents nor students have a correct orientation for national musical instrument learning. National musical instrument is in low status of quality education and basic music education, which seriously affects the development and inheritance of it. Therefore, we must change our mindset and lay emphasis on the reform and development of national musical instrument teaching in quality education and basic music education. ${ }^{[5]}$ For cultural heritage, national musical instrument is valuable and should be carried out and inherited actively by us. Setting corresponding curriculums at school is to promote and inherit national musical instrument, which is the obligation for each citizen.

The key to education reform lies in the development and improvement of teaching staff. An important step of educational reform of national musical instrument in quality education and basic music education is to optimize the teaching staff and constantly improve the quality of teachers themselves. Firstly, we must enhance the knowledge and ability of music teachers in national musical instrument constantly. ${ }^{[6]}$ Secondly, the structure of teaching staff should be optimized. Finally, we must strictly enforce the teacher's assessment system. The teacher's own teaching level and teaching quality are related to the quality of students' training directly. The assessment of the teachers should be noticed in educational reform of national musical instrument in quality education and basic music education and different rewards and punishments should be set according to the performance of the teachers in the teaching activities so as to effectively mobilize the initiative and enthusiasm of teachers to improve teaching quality.

For educational reform of national musical instrument in quality education and basic music education, it is required to transform traditional classroom teaching pattern and pay attention to art practice of students. The main purpose of carrying out national musical instrument teaching is to 
inherit and carry forward the excellent national culture of our country, to improve traditional cultural accomplishment of students, to help students master the playing methods of some musical instruments and gain a skill as well as comprehensive quality of students. However, just some theoretical knowledge is acquired by students in the traditional classroom teaching and the process of learning is boring, which affects the passion and enthusiasm of students seriously. So, it is urgent to reform the traditional teaching mode and pay attention to the study of art practice courses. Only in this way can the national musical instruments be better inherited.

For students' growth and development, national musical instrument education in quality education and basic music education is of important significance and function. Therefore, we need to improve awareness constantly and start educational reform of national musical instrument in order to enhance art attainment and cultural deposits of students. At the same time, we should call on and spread our excellent traditional culture to make national culture present its glamour.

\section{References}

[1] Zhang Lihong. Research on National Music Teaching in Primary and Middle Schools under Multicultural Background_—Problems and Countermeasures [D]. Northeast Normal University, 2012.

[2] Wang Qingtao. Research on National Musical Instrument Education in High School Music Course [D]. Inner Mongolia Normal University, 2015.

[3] Li Wei. Teaching Research on National Instrumental Music in Middle School Music Education [D]. Sichuan Normal University, 2015.

[4] Liu Xin. Investigation and Strategy Research on the Current Situation of Ethnic Music Teaching in Primary Schools in Hunan Province [D]. Hunan Normal University, 2014.

[5] Xiao Wenwen. Research on Basic Music Education in China under the International Understanding Education Concept [D]. Ludong University, 2014.

[6] Yue Xinxin. Reform and Innovation of Basic Music Education Performance Class [D]. Luoyang Teachers College, 2015 